\title{
Pathogenicity of Vibrio tapetis, the etiological agent of brown ring disease in clams
}

\author{
Bassem Allam $^{1,2}$, Christine Paillard ${ }^{1}$, Susan E. Ford ${ }^{2, *}$ \\ ${ }^{1}$ Institut Universitaire Européen de la Mer, UMR 6539, Université de Bretagne Occidentale, Technopôle Brest-Iroise, \\ 29280 Plouzané, France \\ ${ }^{2}$ Haskin Shellfish Research Laboratory, Rutgers University, 6959 Miller Avenue, Port Norris, New Jersey 08349, USA
}

\begin{abstract}
Brown ring disease (BRD) causes high mortalities in the introduced Manila clam Ruditapes philippinarum cultured in western Europe. The etiological agent of BRD, Vibrio tapetis, adheres to and disrupts the production of the periostracal lamina, causing the anomalous deposition of periostracum around the inner shell. Because the primary sign of BRD is found outside the soft tissues, the processes leading to death are not as obvious as those for internal pathogens. This study was designed to evaluate the pathogenicity of $V$. tapetis, in an attempt to help explain the mechanisms of mortality. We found high mortalities (up to $100 \%$ ) for clams following the inoculation of $V$. tapetis into the extrapallial space (between mantle and inner shell) or the posterior adductor muscle of healthy $R$. philippinarum. Microscopy and immunological detection methods showed that the pathogen was rapidly eliminated from tissues and hemolymph of animals that survived the inoculation. In clams that died, the bacteria were found to have proliferated, resulting in severe tissue disruption. Bacteria were able to penetrate into tissues from the extrapallial space through the external epithelium of the mantle. In contrast, no mortalities were observed following injection of $V$. tapetis in the native European clam Ruditapes decussatus, which is resistant to BRD. This clam rapidly eliminated the bacterium from hemolymph and soft tissues. Clam mortality associated with BRD in the field is likely to result from the penetration of $V$. tapetis into the clam's extrapallial space through the disrupted periostracal lamina and from there into the soft tissues through the irritated mantle epithelium. Some bacteria also penetrate through the digestive epithelia. In either case, bacteria proliferate rapidly in the soft tissues, causing severe damage and subsequent death.
\end{abstract}

KEY WORDS: Bivalve $\cdot$ Bacteria $\cdot$ Mortality $\cdot$ Disease progression $\cdot$ Immunofluorescence $\cdot$ Enzymelinked immunosorbent assay

Resale or republication not permitted without written consent of the publisher

\section{INTRODUCTION}

In Europe, brown ring disease (BRD) affects the clam Ruditapes philippinarum, a species introduced for aquaculture in the 1970s. The disease was first recognized in 1987 in France, causing high mortalities and severe losses in cultured stocks. The etiological agent of BRD, a pathogenic bacterium named Vibrio tapetis, invades the clam's pallial (mantle) cavity, where it adheres to the periostracal lamina at the growing edge of the shell (Paillard et al. 1994, Borrego et al. 1996a).

*Corresponding author. E-mail: susan@hsrl.rutgers.edu
Subsequent disruption of periostracal deposition allows the bacterium to penetrate into the extrapallial space and results in a brown organic deposit on the inner shell, which gives the disease its name. In severely diseased clams, V. tapetis has been detected using immunological methods within cells of the digestive diverticula (Plana 1995), in the extrapallial fluid (Allam et al. 2000b), and within the connective tissue of the mantle (Santamaria et al. 1995). These observations were associated with degeneration of the digestive diverticula and hypertrophy of the mantle (Plana \& Le Pennec 1991, Paillard 1992, Plana et al. 1996). However, the process leading to the death of diseased 
clams is still not well understood and the relationship between the presence of the pathogen within tissues and clam death has not been established.

In experimental pathology, inoculation directly into tissues is a useful way to test the pathogenicity of microbes to mollusks (Tubiash 1971). This method allows the pathogen to avoid external defense factors of the host at the shell and epithelial levels (biological, physical, and chemical defenses). Once bacteria are present within host tissues, one of the following conditions can ensue: (1) bacteria are able to avoid the defense system of the host, proliferate, and, by means of their toxicity factors, threaten the vital processes of the host; or (2) the host is able to neutralize and eliminate bacteria using its humoral and cellular defense capacities (Chu 1988, Millar \& Ratcliffe 1994). This elimination process is primordial in all invertebrates since it preserves animal integrity and restricts damages caused by microbes (Bayne 1983, Millar \& Ratcliffe 1994).

Generally, the ability of the internal defense system of invertebrates to eliminate bacteria is inversely correlated with the pathogenicity of these microorganisms (Hartland \& Timoney 1979, De La Pena et al. 1995). Thus, virulent strains proliferate in the circulatory compartment, whereas others are eliminated in relatively short time (a few hours to a few days). In the case of BRD, the injection of Vibrio tapetis directly into the clam's internal (soft tissue) and pseudo-internal (extrapallial, between mantle and inner shell) compartments could give information on the pathogenicity of this strain and on the efficiency of the neutralization and elimination mechanisms of the host.

This paper describes results obtained following injection of Vibrio tapetis into the posterior adductor muscle, the extrapallial space (between the shell and outer mantle epithelium), and the pallial (mantle) cavity of Ruditapes philippinarum. The parameters investigated were clam survival, in vivo bacterial clearance, in vitro phagocytosis, and damage observed in tissue sections. The pathogenicity of $V$. tapetis was compared with that of $V$. anguillarum, a pathogen of bivalve larvae. The response of the native clam $R$. decussatus, known to be highly resistant to BRD (Maes \& Paillard 1992), was compared with that of $R$. philippinarum.

\section{MATERIALS AND METHODS}

Clams and bacteria. Adult (34.2 $\pm 0.8 \mathrm{~mm})$ Ruditapes philippinarum and $R$. decussatus with no clinical signs of BRD were harvested from the Bay of Brest (France) and maintained in aerated marine aquaria at $14^{\circ} \mathrm{C}$ throughout the experiments. They were fed cultured algae daily throughout the study. Vibrio tapetis (ATCC
4600) had been previously isolated from diseased clams (isolate P16; Paillard et al. 1997). V. anguillarum (ATCC 12336) was kindly provided by the Micromer Laboratory (Brest, France). An unidentified non-Vibrionaceae bacterial strain (R2) frequently encountered in apparently healthy clams was isolated and used as a control in injection experiments to compare its effects with those of both Vibrio sp.

Injection experiments. Injection of different clam species with different bacterial species: Bacteria, cultured on marine agar (1 1 distilled water, $15 \mathrm{~g}$ agar, $20 \mathrm{~g}$ sea salts [Sigma], $4 \mathrm{~g}$ peptone, $\left.0.1 \mathrm{~g} \mathrm{Fe}\left(\mathrm{PO}_{4}\right)_{2}\right)$ and reaching the exponential phase of growth (typically 60 to $72 \mathrm{~h}$ at $20^{\circ} \mathrm{C}$ ), were suspended in sterile seawater (SSW; filtered at $0.22 \mu \mathrm{m}$ then autoclaved) and adjusted spectrophotometrically to about $5 \times 10^{8}$ colonyforming units (CFU) $\mathrm{ml}^{-1}$. Four different batches of Ruditapes philippinarum ( $\mathrm{n}=180 \mathrm{clams} \mathrm{batch}^{-1}$ ) were separately inoculated within the posterior adductor muscle with $0.1 \mathrm{ml}\left(5 \times 10^{7} \mathrm{CFU}\right)$ of different bacteria (live Vibrio tapetis, dead V. tapetis, live V. anguillarum, and live R2). Dead $V$. tapetis were obtained by heating the bacterial suspension to $60^{\circ} \mathrm{C}$ for $2 \mathrm{~h}$. A fifth batch of 180 clams was injected with SSW as a control. Two batches of $R$. decussatus of 60 clams each were separately injected with live $V$. tapetis or SSW. Each batch of clams was maintained at $14^{\circ} \mathrm{C}$ in a separate aquarium at about 180 clams m${ }^{-2}$. Clams (10 R. philippinarum and $6 R$. decussatus) were sampled at time intervals of $5 \mathrm{~min}, 2 \mathrm{~h}, 6 \mathrm{~h}$, and 1, 3, 7, and $14 \mathrm{~d}$ following challenge. Hemolymph was withdrawn from the adductor muscle of each clam as previously described (Allam \& Paillard 1998). Bacterial clearance from the hemolymph was measured using an enzyme-linked immunosorbent assay (ELISA) (see below). Dead clams were immediately removed and recorded. Cumulative mortality was calculated over the 2 week experiment from the number of remaining clams after each sampling.

Injection with different doses of Vibrio tapetis: Another experiment was performed to measure the effect of the dose of injected live $V$. tapetis on the survival of Ruditapes philippinarum. Six batches of clams ( $\mathrm{n}=50$ clams batch $^{-1}$ ) were prepared. Three batches were injected with $0.1 \mathrm{ml}$ of suspensions containing the following doses of bacteria: $10^{9} \mathrm{CFU}, 5 \times 10^{7} \mathrm{CFU}$, and $10^{6} \mathrm{CFU} \mathrm{clam}^{-1}$. A fourth batch was injected with SSW. The remaining 2 batches were injected with $10^{9}$ or $10^{6} \mathrm{CFU}$ clam $^{-1}$, labeled according to dose, and incubated together in the same tank to see whether resulting mortality was strictly related to the inoculated dose of the pathogen or affected by bacteria in the surrounding seawater. Dead clams were immediately removed and counted, and cumulative mortality was calculated over the 2 wk experiment. 
Injection with extracellular products of Vibrio tapetis: A culture of $V$. tapetis was grown in marine broth (1 1 distilled water, $20 \mathrm{~g}$ sea salts [Sigma], $4 \mathrm{~g}$ peptone, $\left.0.1 \mathrm{~g} \mathrm{Fe}\left(\mathrm{PO}_{4}\right)_{2}\right)$. Cells were harvested in the exponential phase, adjusted to about $5 \times 10^{8} \mathrm{CFU} \mathrm{ml}^{-1}$, and divided into 2 subcultures. One of the subcultures was filtered through a $0.2 \mu \mathrm{m}$ polycarbonate membrane. Culture filtrate, containing extracellular products of the pathogen, was inoculated $\left(100 \mu \mathrm{llam}^{-1}\right)$ into the adductor muscle of 50 Ruditapes philippinarum. Another batch of 50 clams was injected with unfiltered culture (bacteria plus medium, $100 \mu \mathrm{l} \mathrm{clam}^{-1}$ ). A control batch of 50 clams was injected with sterile culture broth $\left(100 \mu \mathrm{l} \mathrm{clam}^{-1}\right)$. Dead clams were immediately removed and counted, and cumulative mortality was calculated over the 2 week experiment.

Injection within the extrapallial space: Five hundred Ruditapes philippinarum were separated into 10 equal batches of 50 clams each. The first batch was inoculated with live Vibrio tapetis in the extrapallial space as follows: a hole was made using a round dental burr in the central part of the shell, without cutting the mantle (Allam \& Paillard 1998). Bacteria $\left(5 \times 10^{7} \mathrm{CFU}\right.$ in $0.1 \mathrm{ml} \mathrm{clam}^{-1}$ ) were injected into the extrapallial space between the mantle and the shell. The hole in the shell was then sealed with a piece of sterile glass coverslip and dental paste. The same $V$. tapetis inoculum was injected into the posterior adductor muscle or the pallial (gill) cavity of 2 additional batches. Similarly, 2 sets of control batches were made. The first set (3 batches) was inoculated with live cells of the nonpathogenic strain (R2, $5 \times 10^{7} \mathrm{CFU}$ in $0.1 \mathrm{ml} \mathrm{clam}^{-1}$ ) in the extrapallial compartment, the adductor muscle, or the pallial cavity, whereas the second set ( 3 batches) was injected with $0.1 \mathrm{ml} \mathrm{SSW}$ in to the same locations. The last batch was not treated to provide a non-disturbed control. Each batch was incubated in a separate tank. Dead clams were immediately removed and counted, and cumulative mortality was calculated over the 2 week experiment.

Detection of Vibrio tapetis. Histology: Histological analysis was designed to detect $V$. tapetis in tissues and bodily fluids of contaminated and control Ruditapes philippinarum and $R$. decussatus. (Allam et al. 1996a). Particular attention was paid to the examination of moribund and non-moribund clams in contaminated batches in order to attempt to understand the causes of clam death. After fixation in fresh aqueous Bouin's solution for 1 week, the tissues were dehydrated in a graded ethanol and xylene series, and embedded in paraffin. Paraffin sections (5 $\mathrm{mm}$ thick) were stained according to Brown \& Hopps (1973) to detect Gram-positive and -negative bacteria or subjected to the immunofluorescence detection technique described below.
Indirect immunofluorescence: An indirect immunofluorescence method using an anti-Vibrio tapetis rabbit serum was used to identify $V$. tapetis in cytospin-prepared hemolymph smears and clam (Ruditapes philippinarum and $R$. decussatus) tissue sections (Allam et al. 1996a). Preparations were rinsed in $0.1 \mu \mathrm{M}$ phosphate buffered saline (PBS; $\mathrm{pH} 7.4$ ) and covered with a normal goat serum (20\% in PBS, 30 min at room temperature). After rinsing with PBS, the primary antibody (rabbit anti-V. tapetis, $0.5 \%$ in PBS) was applied to the slides, which were placed in a moist chamber. After incubation for $1 \mathrm{~h}$ at $30^{\circ} \mathrm{C}$, preparations were abundantly rinsed with $\mathrm{PBS}$, then covered by $1 \%$ fluorescein isothyocyanate-conjugated goat anti-rabbit antibody in PBS containing $1 \%$ bovine serum albumin for $45 \mathrm{~min}$ at $30^{\circ} \mathrm{C}$. The preparations were then rinsed 3 times with PBS and mounted in non-fluorescent microscopic oil before examination under epifluorescence illumination. Smears of both V. tapetis and other Vibrio sp. were subjected to the same treatments to constitute positive and negative controls, respectively.

ELISA: An ELISA was used to measure Vibrio tapetis burdens in the hemolymph of Ruditapes philippinarum and $R$. decussatus previously injected in the adductor muscle with various bacteria. Only clams that did not present signs of weakness (mainly difficulty in closing their valves) were analyzed. After hemolymph collection, plasma and cell pellets were immediately separated after gentle centrifugation $(200 \times g$ for $20 \mathrm{~min}$ at $\left.4^{\circ} \mathrm{C}\right)$. Pellets were rinsed 3 times with an EDTA-PBS (1 1 distilled water, $14.4 \mathrm{~g} \mathrm{Na}_{2} \mathrm{HPO}_{4} \cdot 2 \mathrm{H}_{2} \mathrm{O}, 2.6 \mathrm{~g}$ $\mathrm{NaH}_{2} \mathrm{PO}_{4} \cdot \mathrm{H}_{2} \mathrm{O}, 25 \mathrm{~g} \mathrm{NaCl}, 10 \mathrm{~g}$ EDTA, $\mathrm{pH}$ 7.4) to detach adhered bacteria from the hemocytes. Cells were then lysed by adding Triton X-100 (0.1\% in SSW). The bacterial burdens in the plasma and the cell lysate were determined using an ELISA previously developed for the detection of $V$. tapetis (Noël et al. 1996) and modified by Allam (1998). Samples were dispensed in triplicate into wells of 96 well microtiter plates and incubated overnight at $4^{\circ} \mathrm{C}$. Unbound material was removed by washing the wells 5 times with PBS. Then PBS containing $1 \%$ Tween and $1 \%$ bovine serum albumin was added to the wells and the plates were incubated for $1 \mathrm{~h}$ at $37^{\circ} \mathrm{C}$. After abundant rinsing with PBS, mouse anti- $V$. tapetis monoclonal antibody 18F10 (Noël et al. 1996) was added to each well and incubated for $1.5 \mathrm{~h}$ at $37^{\circ} \mathrm{C}$. Plates were then washed 3 times with PBS, and the secondary antibody (goat antimouse immunoglobulins linked with biotin) was added and incubated for $1.5 \mathrm{~h}$ at $37^{\circ} \mathrm{C}$. Plates were then washed as before and incubated with ExtrAvidine (Sigma) labeled with horseradish peroxidase for $1.5 \mathrm{~h}$ at $37^{\circ} \mathrm{C}$. After rinsing 3 times with PBS, $100 \mu \mathrm{l}$ of the substrate solution $(0.067 \%$ o-phenylendiamine di-HCl in citric acid-phosphate buffer ( $\mathrm{pH} 5$ ) added with $0.1 \%$ 
$\mathrm{H}_{2} \mathrm{O}_{2}$ ) was added. The reaction was allowed to proceed for $15 \mathrm{~min}$ at room temperature and then stopped by adding $100 \mu \mathrm{l}$ of sulfuric acid ( $2 \mathrm{~N}$ ) to each well. The optical density of each sample was read at $492 \mathrm{~nm}$ using a microplate reader and related to a standard curve made with known concentrations of $V$. tapetis.

In vivo phagocytosis of Vibrio tapetis. $V$. tapetis was grown in marine broth for $12 \mathrm{~h}$, then labeled with the vital dye cyanoditolyl tetrazolium chloride (CTC; $1 \mathrm{mM}$ ) as previously described (Allam et al. 1996b). Approximately $5 \times 10^{7}$ labeled bacteria in $100 \mu \mathrm{lSW}$ were injected into the posterior adductor muscle $(\mathrm{n}=$ $70)$ or the extrapallial space $(\mathrm{n}=36)$ of each Ruditapes philippinarum. Control animals were injected with SSW ( $\mathrm{n}=34$ and 18, respectively). Test and control clams were maintained in marine aquaria and sampled at intervals from 5 min to $7 \mathrm{~d}$. Hemolymph and extrapallial fluid were withdrawn and immediately fixed $(\mathrm{v} / 5 \mathrm{v})$ in formalin-SSW solution (3\% formalin final concentration). Hemocytes and fluorescent bacteria were counted using a Coulter EPICS C flow cytometer (Model 752) equipped with an argon laser (emission at $488 \mathrm{~nm}$ ). Forward light scatter (FLS) and red fluorescence signals were collected for each of 10000 particles. Free bacteria (red fluorescent particles having a low FLS) and bacteria-associated hemocytes (red fluorescent, high FLS) were gated electronically and their percentage was calculated.

\section{RESULTS}

\section{Adductor-muscle injection \\ Effect of different bacteria}

Dead Ruditapes philippinarum appeared after the 5th day post inoculation in the group injected with Vibrio tapetis in their posterior adductor muscle (Fig. 1). In this batch, which had been injected with $5 \times 10^{7} \mathrm{CFU} \mathrm{clam}^{-1}$, the percentage of dead clams increased rapidly until Day 10 , then stabilized and was about $57 \%$ at Day 14 . In contrast, mortality in clams injected with $V$. anguillarum was about $15 \%$ at Day 14, and final mortality was less than $6 \%$ in $R$. philippinarum injected with dead $V$. tapetis, the non-pathogenic strain R2, or SSW. Injection of $R$. decussatus with live $V$. tapetis did not induce any deaths. BRD signs were not observed in any of the challenged or control batches of either clam species.

\section{Effect of Vibrio tapetis dose}

There was a clear dose-response effect in Ruditapes philippinarum injected with Vibrio tapetis (Fig. 2).

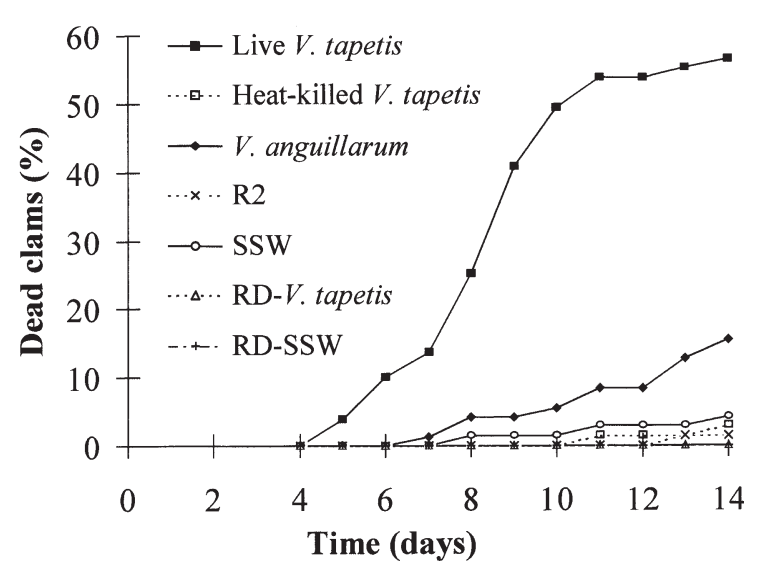

Fig. 1. Ruditapes philippinarum. Cumulative mortality following injection of different bacterial strains into the posterior adductor muscle. R2: non-Vibrionaceae bacterial strain; RD-SSW: $R$. decussatus injected with sterile seawater; RD-V. tapetis: $R$. decussatus injected with live Vibrio tapetis

Cumulative mortality after 2 wk reached a mean of about $80 \%$ in clams injected with $1 \times 10^{9} \mathrm{CFU}$ ind. ${ }^{-1}$, $48 \%$ in those inoculated with $5 \times 10^{7} \mathrm{CFU}$ ind. ${ }^{-1}$, and only $2 \%$ in those injected with $1 \times 10^{6} \mathrm{CFU}_{\text {ind. }}{ }^{-1}$, including the batch that had been incubated in the same aquaria as clams inoculated with $1 \times 10^{9} \mathrm{CFU}$ ind. ${ }^{-1}$ (Fig. 2). Mortality of clams injected with SSW was zero. None of the clams developed BRD signs.

\section{Effect of extracellular factors}

Ruditapes philippinarum inoculated with whole culture of Vibrio tapetis displayed about $60 \%$ mortality at

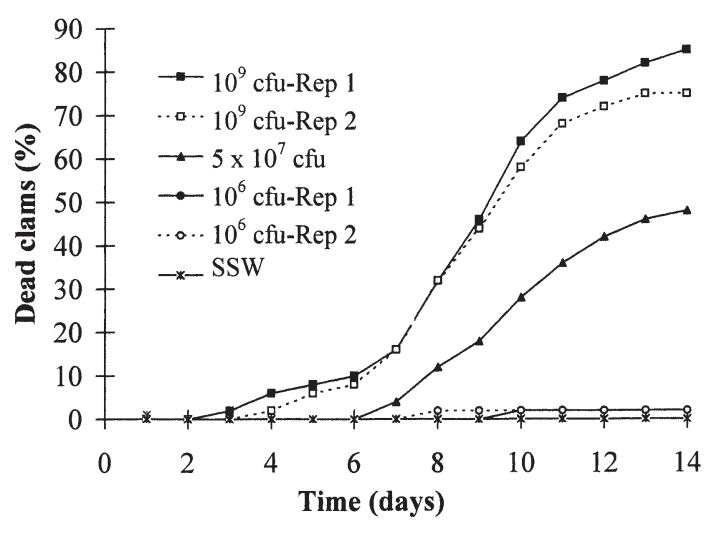

Fig. 2. Ruditapes philippinarum. Cumulative mortality following injection of different doses of Vibrio tapetis into the posterior adductor muscle. $R$. philippinarum of the second repetition (Rep) injected with $10^{9}$ colony-forming units (CFU) ind $^{-1}\left(10^{9}\right.$ CFU-Rep 2) and those inoculated with $10^{6} \mathrm{CFU}$ ind.$^{-1}\left(10^{6}\right.$ CFU-Rep 2) were incubated in the same aquaria. SSW: sterile seawater 


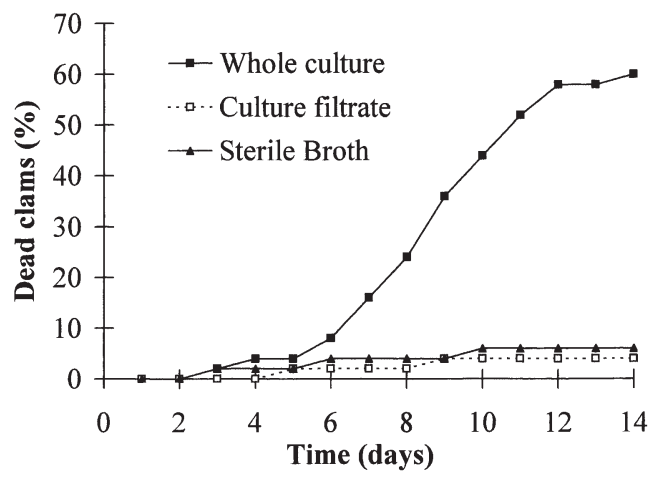

Fig. 3. Ruditapes philippinarum. Cumulative mortality following the injection into the posterior adductor muscle of different fractions of a culture of Vibrio tapetis in marine broth

Day 14 (Fig. 3). In contrast, clams injected with culture filtrate and sterile culture broth experienced only 4 and $6 \%$ mortality, respectively.

\section{Comparison of adductor muscle, extrapallial space, and pallial cavity injection}

The first dead Ruditapes philippinarum appeared at day 2 and day 4 in the batches injected with Vibrio tapetis within the adductor muscle and the extrapallial compartment, respectively (Fig. 4). Cumulative mortality increased rapidly, reaching $100 \%$ at Days 12 and 14 , respectively. Mortality did not exceed $8 \%$ in the other test and control batches, including those injected in the pallial cavity. Clinical signs of BRD appeared

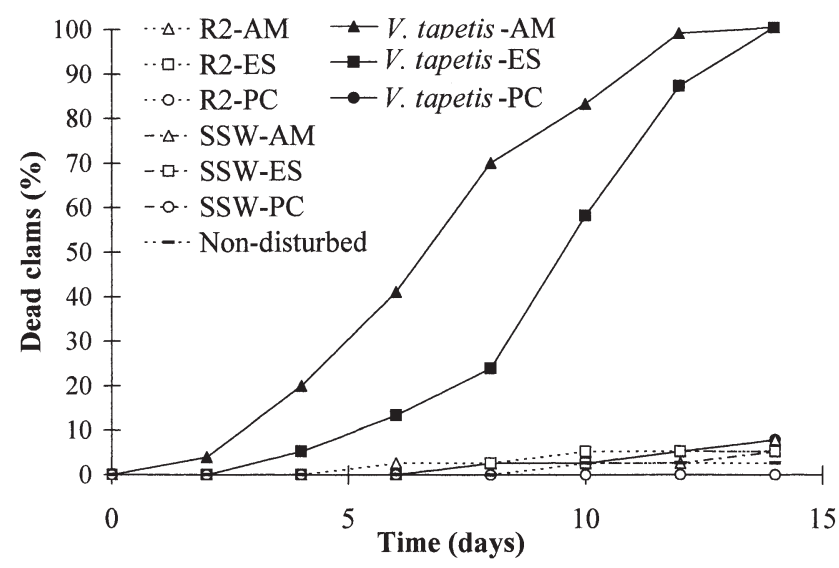

Fig. 4. Ruditapes philippinarum. Cumulative mortality following the inoculation of Vibrio tapetis, the non-Vibrionaceae strain (R2), or sterile seawater (SSW) into the adductor muscle (AM), the extrapallial space (ES) or the pallial cavity (PC) of $R$. philippinarum. The 10th batch was not injected to provide a non-disturbed control only in clams inoculated with $V$. tapetis within the pallial cavity. The percentage of clams showing BRD signs was $42 \%$ at Day 3 and $92 \%$ at Day 14 .

\section{Bacterial burdens in body fluids}

Plasma burdens measured by ELISA

As measured by the ELISA assay, bacterial densities in the plasma of Ruditapes philippinarum injected with live or dead Vibrio tapetis had decreased to less than $0.01 \%$ of the inoculum within $2 \mathrm{~h}$ of injection, although there was considerable individual variability (Fig. 5a,b). Much of this apparent disappearance was undoubtedly due to dilution within the circulatory system. After

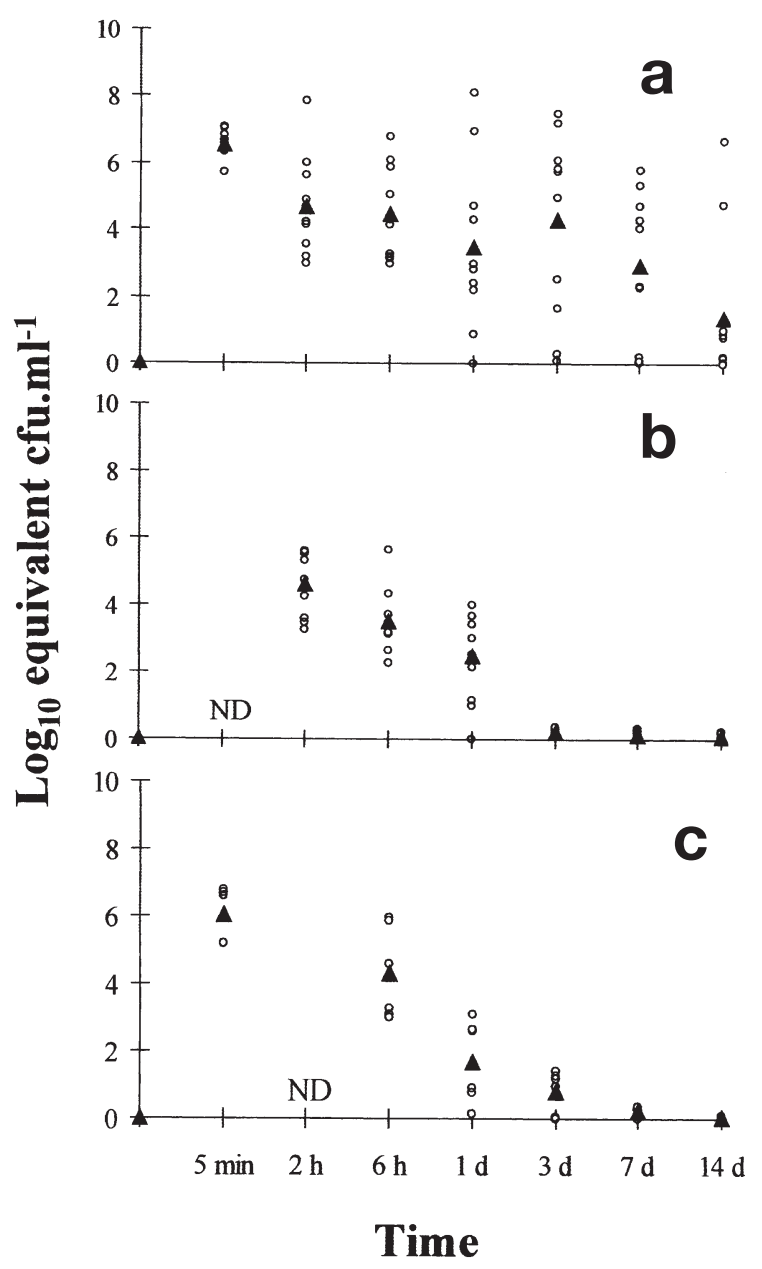

Fig. 5. Bacterial burdens, detected by enzyme-linked immunosorbent assay, in the plasma of individual Ruditapes philippinarum ( $\mathrm{n}=10$ ind. sample ${ }^{-1}$ ) injected in the adductor muscle (a) with live Vibrio tapetis and (b) heat-killed $V$. tapetis, and (c) of $R$. decussatus ( $\mathrm{n}=6$ ind. sample ${ }^{-1}$ ) injected with live $V$. tapetis. Solid triangles represent geometric means. ND: not determined 
$24 \mathrm{~h}$, distinct differences between clam species, and between live and killed bacteria, were apparent (Fig. 5a-c). The mean density in the hemolymph of $R$. philippinarum injected with live $V$. tapetis was an order of magnitude greater than that of the same species injected with dead bacteria or of that in $R$. decussatus injected with live $V$. tapetis. Bacterial densities in $R$. philippinarum injected with live bacteria remained stable between Days 1 and 3, then decreased progressively until the end of the experiment. However, in 2 of 10 clams, the pathogen was completely eliminated by Day 3, and 5 of 10 clams had lost all detectable $V$. tapetis by Day 14 (Fig. 5a). In contrast to the persistence of live bacteria in $R$. philippinarum, detectable heat-killed bacteria had disappeared from the plasma by Day 3 (Fig. 5b). Live bacteria were cleared from the plasma of $R$. decussatus at approximately the same rate; very low densities were found at Day 3 and none thereafter (Fig. 5c).

Phagocytosis and adherence measured by ELISA

The number of Vibrio tapetis detected using ELISA in hemolymph cell lysates of Ruditapes philippinarum inoculated with live bacteria followed the same pattern as in the plasma but with a time shift in the appearance of maximum quantities. Bacteria were found in the lysates within a few minutes of injection (Fig. 6). Live $V$. tapetis associated with hemocytes increased with time and reached maximum values 2 to $6 \mathrm{~h}$ following challenge (Fig. 6a). The pathogen was still detected in hemocyte lysates from 7 of 10 clams at Day 7 , and from 5 of 10 clams at Day 14. Positive responses were no longer detected by Day 7 in clams injected with heatkilled V. tapetis (Fig. 6b). The pathogen was not detected in cell lysates from the native species $R$. decussatus by 3 d post challenge (Fig. 6c).

Phagocytosis and adherence measured by flow cytometry

In hemolymph, the uptake of CTC-labeled Vibrio tapetis by Ruditapes philippinarum hemocytes, as measured by flow cytometry, was observed only a few minutes following the injection (Fig. 7a). The percentage of cells with ingested or adhering bacteria was about $20 \%$ at $30 \mathrm{~min}$, then decreased to zero by Day 3 . The number of bacteria not associated with hemocytes decreased rapidly during the first hours following injection and none were detected by Day 3 (Fig. 7b).

In the extrapallial fluid, the percentage of hemocytes with ingested or adhering bacteria was already about $60 \% 2 \mathrm{~h}$ following challenge (Fig. 7c). It decreased

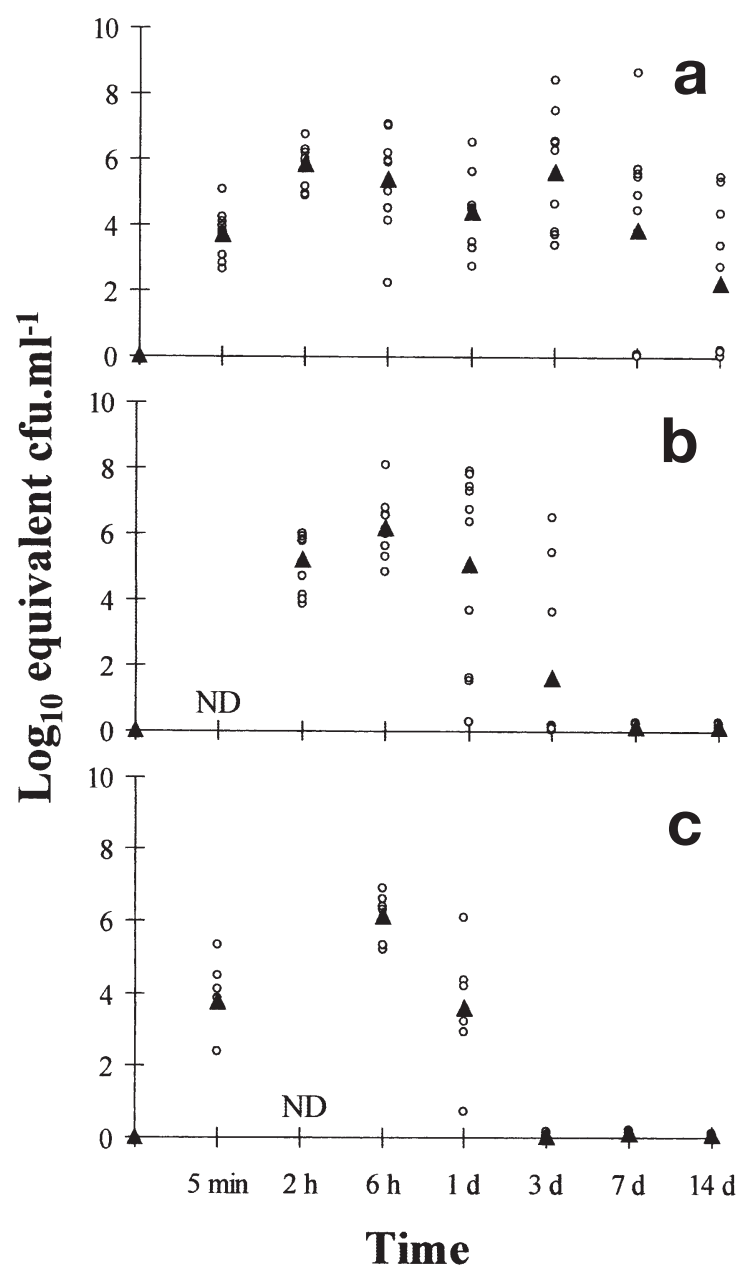

Fig. 6. Bacterial burdens, detected by enzyme-linked immunosorbent assay, in hemocyte lysates of individual Ruditapes philippinarum $\left(\mathrm{n}=10\right.$ ind. sample $\left.{ }^{-1}\right)$, (a) injected in the adductor muscle with live Vibrio tapetis and (b) heat-killed $V$. tapetis, and of $R$. decussatus ( $\mathrm{n}=6$ ind. sample ${ }^{-1}$ ), (c) injected with live $V$. tapetis. Solid triangles represent geometric means. ND: not determined

rapidly to $14 \%$ after $24 \mathrm{~h}$, to $7 \%$ at Day 3, and to zero at Day 7 . The number of free bacteria also decreased rapidly and had completely disappeared $7 \mathrm{~d}$ following challenge (Fig. 7d). No fluorescent particles were detected in hemolymph or extrapallial fluid of clams injected with SSW.

\section{Microscopic detection of Vibrio tapetis}

Numerous Gram-negative bacteria were observed in histological sections of moribund Ruditapes philippinarum that had been inoculated with live Vibrio tapetis in the adductor muscle or extrapallial space. These bacteria were identified as $V$. tapetis using immunofluorescence (Fig. 8). Clams that had received 

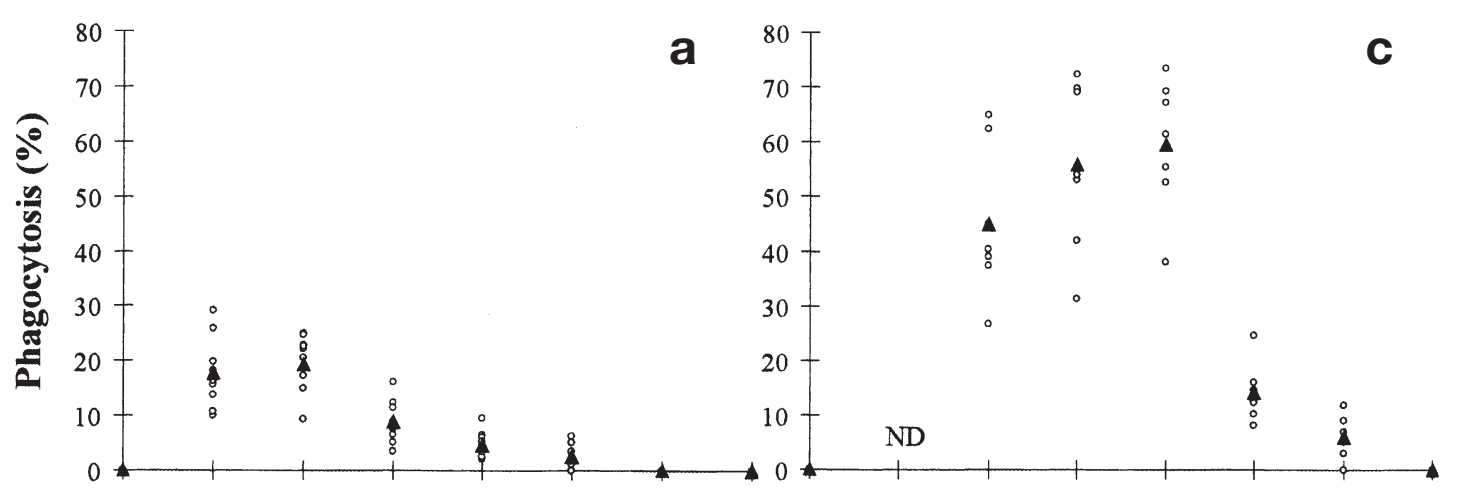

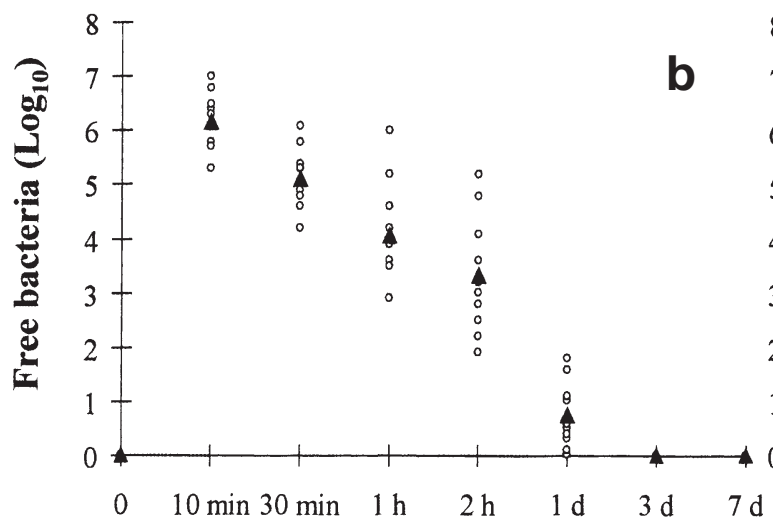

Time

Fig. 7. Clearance of dye cyanoditolyl tetrazolium chloride (CTC)labeled Vibrio tapetis in Ruditapes philippinarum injected in the adductor muscle ( $a$ and $b, n=10$ ind. sample ${ }^{-1}$ ) or the extrapallial space (c and $\mathrm{d}, \mathrm{n}=6$ ind. sample ${ }^{-1}$ ). a and c: percent phagocytosis by hemocytes; $b$ and $d$ : free bacteria $\left(\log _{10}\right.$ bacteria $\left.\mathrm{ml}^{-1}\right)$ in hemolymph and extrapallial fluid, respectively. Solid triangles represent geometric means. ND: not determined

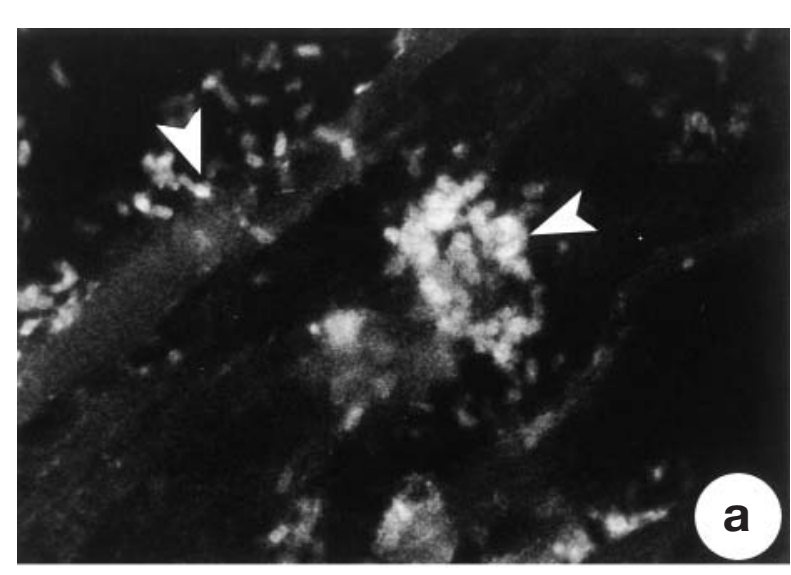

Fig. 8. Microscopic detection of Vibrio tapetis (indirect immunofluorescence technique) within (a) the posterior adductor muscle, (b) the digestive diverticula, and (c) the connective tissue of the mantle of 3 moribund Ruditapes philippinarum previously inoculated with live pathogen cells within the adductor muscle (a and b) or the extrapallial space (c). Arrowheads: bacteria. Scale bar $=5 \mu \mathrm{m}$ (applies to all panels)
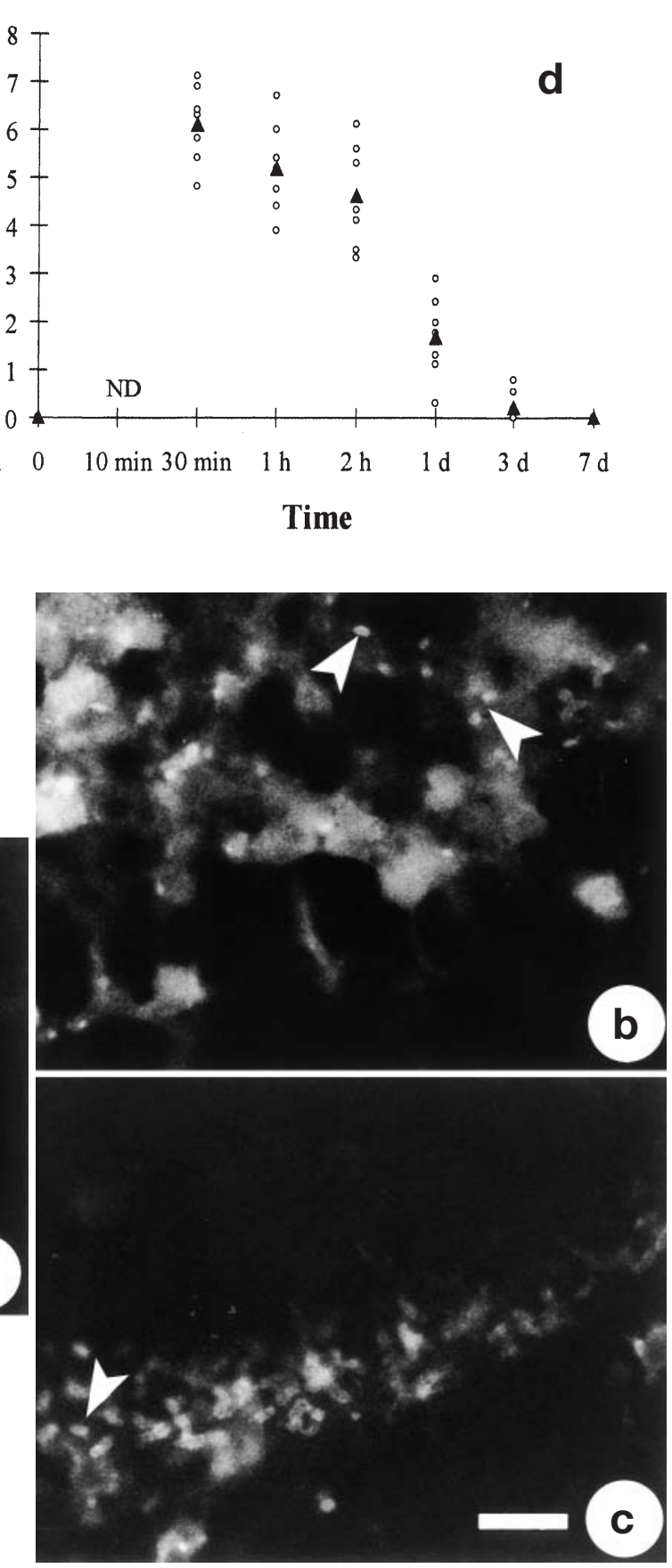
an injection into the muscle showed numerous $V$. tapetis not only in the sinuses between muscle filaments (Fig. 8a) but also inside epithelial and subepithelial cells of the digestive diverticula (Fig. 8b) and gills and within the connective tissue of the mantle (Fig. 8c). Hemolymph smears from moribund clams contained a high number of $V$. tapetis and much cell debris. In clams injected with live $V$. tapetis in the extrapallial space (between the mantle and shell), the epithelium of the mantle was disrupted and eroded. The underlying connective tissue was particularly affected (Fig. 8c). In these moribund animals, numerous $V$. tapetis were also observed in the digestive diverticula and gills. In addition, pathogens were abundant in the extrapallial fluid. Very few $V$. tapetis were detected in sections of 2 out of 10 individual nonmoribund clams; no bacteria were detected in the remaining clams.

Extremely high numbers of Vibrio tapetis were found in the connective tissue of various organs, especially the mantle and digestive diverticula, of dead clams that had been injected with live $V$. tapetis into the muscle or the extrapallial space, and extensive lysis and necrosis of tissues were observed.

Vibrio tapetis was not detected in clams injected with $V$. anguillarum, R2, or SSW, including the few dead or moribund clams present in these batches.

\section{DISCUSSION}

To counter pathogens, bivalves have physical barriers, such as the epithelium, and biological factors, including the internal defense system, to combat pathogens that breach external barriers. Indeed, the success or failure of the host in neutralizing such invading microorganisms depends on both the virulence of the pathogens and the performance of the internal defense factors (Martinez-Manzanares et al. 1991). Results presented here show that both types of defense mechanisms are involved in fighting the etiological agent of BRD, Vibrio tapetis. Histopathological changes and mortalities of the introduced clam, Ruditapes philippinarum, reached $100 \%$ in groups injected directly in the adductor muscle or in the extrapallial space, whereas animals injected in the pallial cavity suffered insignificant mortality. These results indicate the importance of the epithelium and the pallial muscle attachment as external barriers. The comparison between BRD-susceptible $R$. philippinarum and the more resistant native clam $R$. decussatus illustrates the importance of the internal defense system in combating bacteria that are able to breach the external barriers. $R$. philippinarum often failed to eliminate injected $V$. tapetis, allowing the pathogen to proliferate within its tissues and to kill it following inoculation into the adductor muscle or the extrapallial space. In contrast, $R$. decussatus successfully eliminated injected pathogens within a few days. The injection in $R$. philippinarum of heat-killed bacteria and extracellular extracts of $V$. tapetis did not cause death, showing that clam death is related to the activities of live bacteria rather than extracellular virulence factors alone.

BRD is one of the few reported bacterial diseases of marine bivalves. Adult bivalves rarely succumb to bacterial infection in nature; however, experimental challenges resulting in high mortality have been reported for many species: pearl oysters Pinctada maxima, injected in the pallial cavity or the extrapallial space with Vibrio harveyi or Pseudomonas putrefaciens (Dybdahl \& Pass 1985, Pass et al. 1987); oysters Crassostrea gigas or $C$. virginica, immersed in or injected in the pallial cavity with Nocardia crassostreae, V. salmonicida or Aeromonas sp. (Friedman \& Hedrick 1991, Olafsen et al. 1993, Friedman et al. 1998); clams Mya arenaria, and oysters $C$. virginica, injected directly in their soft tissues with $V$. anguillarum (Tubiash 1971, Tubiash et al. 1973); and mussels Dreissena polymorpha, injected with Aeromonas sp. (Maki et al. 1998). The deaths of bivalves in these experiments were associated with massive invasion of tissues and hemolymph by the bacteria. As in our study, the experimental conditions (injection of high bacterial doses, direct injection in tissues or extrapallial space, shell damage) were abnormal. Other studies underscore the resistance of adult bivalves when the contact with bacteria was under more 'normal' conditions such as immersion, even in high concentrations of bacteria, and even when strains known to be pathogenic for larvae are used (e.g. V. anguillarum, V. alginolyticus, several other Vibrio sp., and Aeromonas sp.) (Tubiash et al. 1965, Martin 1976). Similarly, the injection of $V$. tapetis into the pallial cavity of Ruditapes philippinarum does not induce death, although it causes the development of BRD signs (Paillard et al. 1994, Allam et al. 2000a, present study). The ability of many bacteria to induce death when external barriers are breached suggests that these barriers are an important element in the ability of adult bivalves to resist bacterial diseases.

In many challenge studies, the delivery of very high numbers of bacteria to experimental animals also causes disease and death. In our investigations, mortalities of clams were directly related to the injected dose of Vibrio tapetis. According to Sindermann (1990), the outcome of microbial infections is related to the balance between infection pressure of pathogens and the neutralization processes of the host. According to this author, successful establishment of a microbial infection generally results when a pathogen (1) survives the phagocytosis process, (2) develops mecha- 
nisms to avoid phagocytosis, or (3) simply overwhelms the host by its capacity to proliferate faster than it can be eliminated. The relationship between clam mortalities and the inoculated doses of $V$. tapetis $(2 \%$ and $80 \%$ mortality for doses of $1 \times 10^{6} \mathrm{CFU}$ and $1 \times 10^{9} \mathrm{CFU}$ ind. ${ }^{-1}$, respectively) is in accordance with Sindermann's third hypothesis of an overwhelming number of pathogens that saturate the host's defense capacity. When the number of inoculated bacteria is low, most clams, even the susceptible Ruditapes philippinarum, are able to eliminate pathogens from soft tissues and hemolymph and repair damage caused by the infection. Conversely, when clams are injected with large quantities of bacteria, their defense system is simply unable to cope with the overwhelmingly large number of $V$. tapetis, which cause irreversible damage that leads to death. In vitro studies support this argument: during in vitro contact between various Vibrio sp. and mussel hemocytes, Lane \& Birkbeck (1999) and Nottage \& Birkbeck (1990) showed that the percentage of hemocytes killed increased significantly as the ratio of bacteria to hemocytes increased. Similar results were also observed during a preliminary study on in vitro interactions between $R$. philippinarum hemocytes and $V$. tapetis (B. Allam unpubl.).

Virulence factors allow pathogens to invade and proliferate in their hosts, and are an important cause of disease and mortality (Toranzo et al. 1983, Ellis 1991). In pathogenic Vibrio sp., virulence factors include adhesins, proteinases, endo- and exotoxins (hemolysins, cytolysins, ciliostatic factors, etc.), and plasmids coding for iron chelators (Horne 1982, Toranzo et al. 1983, Moustafa et al. 1984, Nottage \& Birkbeck 1986). $V$. tapetis factors include hemolysins, cytotoxins, exotoxins, and plasmids (Borrego et al. 1996b, Castro et al. 1997). In vitro experiments have shown that $V$. tapetis cells are able to kill cultured fish cells and hemocytes of Ruditapes philippinarum (Borrego et al. 1996b, Lane 1997, B. Allam unpubl.). Nevertheless, our results show that extracellular virulence factors alone are not involved in clam mortality; rather, the intact bacterium was needed to cause death. In addition to the production of toxic molecules, several other virulence factors are associated with intact $V$. tapetis. For instance, the bacterium displays a high adhesion capacity associated with the presence of pili (Paillard et al. 1994). Further, the cell wall contains smooth lipopolysaccharides that, according to Bradley (1979), play an important role in virulence by helping the penetration of pathogens into host tissues. They also allow bacteria to better resist the defense system of clams, particularly phagocytosis by hemocytes (Borrego et al. 1996b). In the present study, we noted the persistence of bacteria in clams without obvious signs of weakness (clams sampled for ELISA) and found high concentrations, with severe pathological changes, in moribund clams. The histological results suggest that host death was the result of damage inflicted on host tissues, including the hemocyte components of the defense system, by high numbers of $V$. tapetis.

Given the ability of Vibrio tapetis to proliferate rapidly in the tissues of Ruditapes philippinarum and its failure to do so in $R$. decussatus, it is instructive to compare the internal defense system activities of the 2 species, starting with bacterial clearance rates. In the present study, only 2 of $10 \mathrm{R}$. philippinarum had cleared all detectable $V$. tapetis from their plasma by Day 3 post challenge, while all of the $R$. decussatus had done so. In fact, half the $R$. decussatus had no detectable bacteria after only $1 \mathrm{~d}$. Using ELISA and flow cytometry, our experiments quantifying the uptake of $V$. tapetis by hemocytes suggest that phagocytosis is the major process used by clams to eliminate bacteria from their hemolymph. Hemocytes of both clam species ingested the bacteria within minutes of injection; however, those of $R$. decussatus were much more effective in killing or otherwise eliminating the bacteria than were hemocytes of $R$. philippinarum. Half of the latter still had bacteria associated with hemocytes $14 \mathrm{~d}$ after injection, whereas no bacteria were detected in hemocyte lysates of $R$. decussatus after only $3 \mathrm{~d}$. In fact, bacteria disappeared from the plasma of live $V$. tapetis-injected $R$. decussatus as rapidly as they did from $R$. philippinarum injected with dead bacteria. Non cellular factors, such as lectins (or agglutinins), present in bivalve plasma may also play a role in the clearance process. They are involved in non-self recognition and opsonization and display differential reactivity toward various bacterial strains (Tamplin \& Fisher 1989, Olafsen et al. 1993, Olafsen 1996). The presence of such agglutinins in $R$. philippinarum has not yet been shown, although clumped $V$. tapetis have been observed microscopically in hemolymph smears. Further, in vitro phagocytosis of $V$. tapetis by $R$. philippinarum and $R$. decussatus hemocytes do not seem to be affected by the presence or the absence of soluble hemolymph proteins of each species (LopezCortes et al. 1999).

The differences in phagocytic and clearance rates between the 2 clam species disappeared when heatkilled or CTC-labeled bacteria were injected. These were rapidly and completely eliminated from hemolymph and extrapallial fluid of Ruditapes philippinarum, without causing significant mortality. We previously showed that CTC significantly inhibits the mobility and the growth of Vibrio tapetis (Allam et al. 1996b). Thus, $R$. philippinarum had no trouble eliminating weak or dead $V$. tapetis from its tissues. These results emphasize the specificity of interactions between $V$. tapetis with $R$. philippinarum or $R$. decussatus. 
The molluscan digestive tract is often considered to be the major portal of entry for many pathogens, which accumulate in the connective tissue surrounding digestive organs and can subsequently proliferate in the host and provoke death (Lauckner 1983). In the case of BRD-affected clams, the extrapallial space may constitute an additional entry point. This compartment is bacteriologically sterile in healthy animals (Allam \& Paillard 1998) but contains Vibrio tapetis cells in heavily diseased clams (Allam et al. 2000b). The extrapallial space of clams is physically separated from the pallial cavity and the external medium by a periostracal layer, secreted by the mantle edge and extending to the outer edge of the shell. A further barrier to the central extrapallial compartment is formed by the attachment of the pallial muscle. $V$. tapetis that enter the pallial cavity adhere to and colonize the periostracal lamina of Ruditapes philippinarum. The normal deposition process is disrupted and the periostracal lamina becomes severely disorganized, resulting in the characteristic organic deposit ringing the inner shell. The disruption of the periostracal membrane allows penetration of bacteria into the peripheral extrapallial space, from which they enter the central extrapallial space after disruption of the pallial attachment. Once in the extrapallial space, as the present study shows, V. tapetis can readily penetrate the external mantle epithelium of $R$. philippinarum and proliferate to lethal densities in the soft tissues. A similar disease progression was described during vibriosis in larvae of the eastern oyster Crassostrea virginica (Elston \& Leibovitz 1980) and in juvenile Pacific oysters $C$. gigas, affected by extrapallial abscesses caused by an unknown bacterium (Elston et al. 1999). In addition, V. tapetis, abundant in the pallial cavity fluid of diseased animals (Maes 1992, Allam et al. 1996a), is likely to be ingested in large quantities and may also penetrate into the soft tissues through digestive epithelia, especially of the digestive diverticula. $R$. philippinarum experimentally injected in the pallial cavity with $V$. tapetis develop clinical signs of BRD, indicating that the bacteria have entered the extrapallial space, but they rarely die (Paillard et al. 1994, present study). Thus, the ability of clams to control $V$. tapetis at the extrapallial fluid level appears to be a major factor in the outcome of the disease process. The importance of this site is highlighted by the very high early phagocytic rates of $V$. tapetis injected into the extrapallial space. An infection that remains 'controlled' within the extrapallial space is not lethal even though an extensive brown ring may be deposited. For this disease, bacterial elimination from the hemolymph is a second line of defense. The development of BRD signs in $R$. decussatus injected in the pallial cavity is much less than in R. philippinarum (Paillard et al. 1994). The resistance of $R$. decussatus to BRD and subsequent death (Maes \&
Paillard 1992, Allam 1998) is primarily the result of a strong barrier to infection at the periostracal membrane level and efficient neutralization of any $V$. tapetis that enter the extrapallial cavity; however, any bacteria that might penetrate the soft tissues would also encounter a very effective internal defense system.

Acknowledgements. The authors would like to thank M. Jean-Louis Nicolas (IFREMER-Brest) for his help with the ELISA and M. Alain Le Mercier for his technical assistance. The Vibrio anguillarum strain was provided by the Laboratoire Micromer (Brest).

\section{LITERATURE CITED}

Allam B (1998) The role of bivalve extrapallial fluids in immunological defense. The case of brown ring disease in the Manila clam, Ruditapes philippinarum. PhD thesis, Université de Bretagne Occidentale, Brest

Allam B, Paillard C (1998) Defense factors in clam extrapallial fluids. Dis Aquat Org 33:123-128

Allam B, Paillard C, Maes P (1996a) Effet du nouveau fluorochrome redox, le chlorure de cyanoditolyl tétrazolium (CTC), sur une souche bactérienne du genre Vibrio. Leban Sci Bull 9:1-10

Allam B, Paillard C, Maes P (1996b) Localisation of the pathogen, Vibrio P1, in clams affected with brown ring disease. Dis Aquat Org 27:149-155

Allam B, Paillard C, Auffret M (2000a) Alterations in hemolymph and extrapallial fluid parameters in the Manila clam, Ruditapes philippinarum challenged with the pathogen, Vibrio tapetis. J Invertebr Pathol 76:63-69

Allam B, Paillard C, Howard A, Le Pennec M (2000b) Isolation of the pathogen Vibrio tapetis and defence parameters in brown ring diseased Manila clams, Ruditapes philippinarum, cultivated in England. Dis Aquat Org 41:105-113

Bayne CJ (1983) Molluscan immunobiology. In: Saleuddin ASM, Wilbur KM (eds) The mollusca, Vol 5: Physiology Part 2. Academic Press, New York, p 407-486

Borrego JJ, Castro D, Luque A, Paillard C, Maes P, Garcia MT, Ventosa A (1996a) Vibrio tapetis sp. nov., the causative agent of the brown ring disease affecting cultured clams. Int J Syst Bacteriol 46:480-484

Borrego JJ, Luque A, Castro D, Santamaria JA, MartinezManzanares E (1996b) Virulence factors of Vibrio P1, the causative agent of brown ring disease in the Manila clam, Ruditapes philippinarum. Aquat Living Resour 9:125-136

Bradley SG (1979) Cellular and mollecular mechanisms of action of bacterial endotoxins. Annu Rev Microbiol 33:67-94

Brown RC, Hopps HC (1973) Staining of bacteria in tissue sections: a reliable Gram stain method. Am J Clin Pathol 60: $234-241$

Castro D, Romalde JL, Vila J, Margarinos B, Luque A, Borrego $\mathrm{J}$ (1997) Intraspecific characterization of $V$. tapetis strains by use of pulsed-field gel electrophoresis, ribotyping and plasmid profiles. Appl Environ Microbiol 63:1449-1452

Chu FLE (1988) Humoral defense factors in marine bivalves. Am Fish Soc Spec Publ 18:178-188

De La Pena LD, Nakai T, Muroga K (1995) Dynamics of Vibrio sp. PJ in organs of orally infected Kuruma prawn, Penaeus japonicus. Fish Pathol 30:39-45

Dybdahl R, Pass DA (1985) An investigation of mortality of pearl oyster, Pinctada maxima, in western Australia. Fish Dep West Aust Rep 71:1-78 
Ellis AE (1991) An appraisal of the extracellular toxins of Aeromonas salmonicida ssp. salmonicida. J Fish Dis 14:265-277

Elston RA, Leibovitz L (1980) Pathogenesis of experimental vibriosis in larval American oysters, Crassostrea virginica. Can J Fish Aquat Sci 37:964-978

Elston RA, Frelier P, Cheney D (1999) Extrapallial abscesses associated with chronic bacterial infections in the intensively cultured juvenile Pacific oyster Crassostrea gigas. Dis Aquat Org 37:115-120

Friedman CS, Hedrick RP (1991) Pacific oyster nocardiosis: isolation of the bacterium and induction of laboratory infections. J Invertebr Pathol 57:109-120

Friedman CS, Beaman BL, Chun J, Goodfellow M, Gee A, Hedrick RP (1998) Nocardia crassostreae sp. nov., the causal agent of nocardiosis in Pacific oysters. Int J Syst Bacteriol 48:237-246

Hartland BJ, Timoney JF (1979) In vivo clearance of enteric bacteria from the hemolymph of the hard clam and the American oyster. Appl Environ Microbiol 45:517-520

Horne MT (1982) The pathogenicity of Vibrio anguillarum (Bergman). In: Roberts RJ (ed) Microbial disease of fish. Special publication of the society for general microbiology. Academic Press, London, p 171-187

Lane E (1997) Bacterial association with commercially important marine bivalves. $\mathrm{PhD}$ thesis, University of Glasgow

Lane E, Birkbeck TH (1999) Toxicity of bacteria towards haemocytes of Mytilus edulis. Aquat Living Resour 12: 343-350

Lauckner G (1983) Diseases of Mollusca: Bivalvia. In: Kinne O (ed) Diseases of marine animals. Biologische Anstalt Helgoland, Hamburg, p 477-962

Lopez-Cortes L, Castro D, Navas JI, Borrego JJ (1999) Phagocytic and chemotactic responses of Manila and carpet shell clam haemocytes against Vibrio tapetis, the causative agent of brown ring disease. Fish Shellfish Immunol 9:543-555

Maes P (1992) Pathologie bactérienne chez deux invertébrés marins d'intérêt commercial, Ruditapes philippinarum et Paracentrotus lividus. PhD thesis, Université de Bretagne Occidentale, Brest

Maes P, Paillard C (1992) Effet de Vibrio P1, pathogène de Ruditapes philippinarum sur d'autres espèces de bivalves. Haliotis 14:141-148

Maki JS, Patel G, Mitchell R (1998) Experimental pathogenicity of Aeromonas spp. for the zebra mussel, Dreissena polymorpha. Curr Microbiol 36:19-23

Martin YP (1976) Importance des bactéries chez les mollusques bivalves. Haliotis 7:97-103

Martinez-Manzanares E, Egea F, Castro D, Morinigo MA, Romero P, Borrego JJ (1991) Accumulation and depuration of pathogenic and indicator microorganisms by the bivalve mollusc, Chamelea gallina L., under controlled laboratory conditions. J Food Prot 54:612-618

Millar DA, Ratcliffe NA (1994) Invertebrates. In: Turner RJ (ed) Immunology: a comparative approach. John Wiley \& Sons, New York, p 29-67

Moustafa $M$, Kodama $\mathrm{H}$, Ishiguro $\mathrm{S}$, Mikami $\mathrm{T}$, Izawa $\mathrm{H}$ (1984) Partial purification of extracellular toxic material of fish vibrios. Am J Vet Res 45:2208-2210

Noël T, Nicolas JL, Boulo V, Mialhe E, Roch P (1996) Development of a colony-blot ELISA assay using monoclonal antibodies to identify Vibrio P1 responsible for 'brown ring disease' in the clam Tapes philippinarum. Aquaculture 146: $171-178$

Nottage AS, Birkbeck TH (1986) Toxicity to marine bivalves of culture supernatant fluids of the bivalve-pathogenic
Vibrio strain NCMB 1338 and other marine vibrios. J Fish Dis 9:249-256

Nottage AS, Birkbeck TH (1990) Interactions between different strains of Vibrio alginolyticus and hemolymph fractions from adult Mytilus edulis. J Invertebr Pathol 56:15-19

Olafsen JA (1996) Lectins: models of natural and induced molecules in invertebrates. In: Cooper EL (ed) Invertebrate immune responses: cells and molecular products. Springer-Verlag, Heidelberg, p 49-76

Olafsen JA, Mikkelsen HV, Viaever HM, Hansen GH (1993) Indigenous bacteria in hemolymph and tissues of marine bivalves at low temperatures. Appl Environ Microbiol 59: $1848-1854$

Paillard C (1992) Etiologie et caractérisation de la maladie de l'anneau brun chez la palourde d'élevage, Ruditapes philippinarum. PhD thesis, Université de Bretagne Occidentale, Brest

Paillard C, Maes P, Oubella R (1994) Brown ring disease in clams. Annu Rev Fish Dis 4:219-240

Paillard C, Maes P, Mazurié J, Claude S, Marhic A, Le Pennec $M$ (1997) Epidemiological survey of the brown ring disease in clams of Atlantic coast: role of temperature in variations of prevalence. Proceeding of the 8th Symposium of the International Society for Veterinary Epidemiology and Economics. Association pour l'Etude de l'Epidémiologie des Maladies animales, Paris, p 8-11

Pass DA, Dybdal R, Mannion MM (1987) Investigations into the causes of mortality of the pearl oyster, Pinctada maxima (Jamson), in western Australia. Aquaculture 65: $149-169$

Plana S (1995) Perturbations de la glande digestive et du métabolisme chez la palourde aquacole, Ruditapes philippinarum, affectée par la maladie de l'anneau brun. PhD thesis, Université de Bretagne Occidentale, Brest

Plana S, Le Pennec M (1991) Altération de la glande digestive et conséquences nutritionnelles chez la palourde Ruditapes philippinarum contaminée par une bactérie du genre Vibrio. Aquat Living Resour 4:255-264

Plana S, Sinquin G, Maes P, Paillard C, Le Pennec M (1996) Variations in biochemical composition of juvenile Ruditapes philippinarum infected by a Vibrio sp. Dis Aquat Org 24:205-213

Santamaria JA, Castro D, Luque A, Martinez-Manzanares E, Borrego JJ (1995) Histological alterations associated with brown ring disease. Proceeding of the First International Workshop on Shell Disease in Marine Invertebrates: Environment-host-pathogen interactions. Université de Bretagne Occidentale (Brest), p 29-31

Sindermann CJ (1990) Principal diseases of marine fish and shellfish. Academic Press, San Diego, p 413-416

Tamplin ML, Fisher WS (1989) Occurrence and characteristics of agglutination of Vibrio cholera by serum from the eastern oyster, Crassostrea virginica. Appl Environ Microbiol 55:2882-2887

Toranzo AE, Barja JL, Colwell RR, Hetrick FM (1983) Characterization of plasmids in bacterial fish pathogens. Infect Immun 39:184-192

Tubiash HS (1971) Soft-shell clam, Mya arenaria, a convenient laboratory animal for screening pathogens of bivalve mollusks. Proc Malacol Soc Lond 22:321-324

Tubiash HS, Channey PE, Leifson E (1965) Bacilary necrosis, a disease of larval and juvenile bivalve mollusks. I. Etiology and epidemiology. J Bacteriol 90:1036-1044

Tubiash HS, Otto SV, Hugh R (1973) Cardiac edema associated with Vibrio anguillarum in the American oyster. Proc Natl Shellfish Assoc 63:39-42

Submitted: December 8, 2000; Accepted: August 20, 2001

Proofs received from author(s): March 11, 2002 